\title{
Prolonged elevation of serum tryptase resulting from intraoperative anaphylaxis to methylene blue
}

\author{
Sacha Oomah ${ }^{1}$, Tom Dembinski ${ }^{2}$, Allan Becker ${ }^{1,3}$, Chrystyna Kalicinsky ${ }^{1,3^{*}}$ \\ From Canadian Society of Allergy and Clinical Immunology Annual Scientific Meeting 2010 \\ Victoria, Canada. 3-6 November 2010
}

\section{Background}

Intraoperative anaphylaxis during sentinel lymph node biopsy is a well known phenomenon occurring with administration of patent blue and isosulfan blue dyes, with an incidence of $2.2 \%$ and $1.1 \%$, respectively $(1,2)$. Methylene blue has been reported as being a safer alternative with only a few case reports demonstrating anaphylaxis and large studies demonstrating no incidence of anaphylaxis in 224 patients $(3,2)$.

\section{Case report}

A 62 year old female undergoing sentinel lymph node biopsy and right lumpectomy was administered methylene blue alongside anaesthetics. Two minutes after administration of methylene blue, the patient entered anaphylactic shock with hypotension, discolouration, and angioedema. Fluid, steroids, and vasopressors were administered and the patient stabilized, at which point the operation continued. Serum taken an hour after anaphylaxis demonstrated a tryptase of $34 \mathrm{ng} / \mathrm{ml}$. A sample six hours later demonstrated prolonged elevation of tryptase at $58 \mathrm{ng} / \mathrm{ml}$. A baseline sample was within normal limits $(<12 \mathrm{ng} / \mathrm{ml})$ at $3 \mathrm{ng} / \mathrm{ml}$. Skin prick and intradermal testing was negative for penicillin, ancef, latex, rocuronium, and propofol. Intradermal testing, however, was positive for methylene blue at $1 / 10$, although a non-irritating concentration has yet to be established.

\section{Discussion}

Serum tryptase peaks at one to two hours post anaphylaxis with a subsequent half-life of two hours (4). We demonstrate tryptase levels that increase with time, rather than decrease, subsequent to exposure to methylene blue. Serum tryptase levels in response to methylene blue anaphylaxis have not been reported previously.

\section{Conclusion}

Methylene blue can cause anaphylaxis with a prolonged elevation of serum tryptase levels.

\section{Author details}

${ }^{1}$ University of Manitoba, Winnipeg, Manitoba, Canada, R3E 3P5. ${ }^{2}$ Diagnostic Services of Manitoba, Winnipeg, Manitoba, Canada, R2H 2A6. ${ }^{3}$ Allergy and Clinical Immunology, Health Sciences Center, Winnipeg, Manitoba, R3A 1R9.

Published: 4 November 2010

\section{References}

1. Haque R, Wagner A, Whisken J, Nasser S, Ewan P: Anaphylaxis to patent blue V: a case series and proposed diagnostic protocol. Allergy 2009, 65:396-400.

2. Teknos D, Ramcharan A, Oluwole S: Pulmonary edema associated with methylene blue dye administration during sentinel lymph node biopsy. J Natl Med Assoc 2008, 100:1483-1484.

3. Jangjoo A, Forghani M, Mehrabibahar M, Sadeghi R: Anaphylaxis reaction of breast cancer patient to methylene blue during breast surgery with sentinel node mapping. Acta Oncologica 2010, 46:877-878.

4. Schwartz L, Yunginger J, Miller J, Bokhari R, Dull D: Time course of appearance and disappearance of human mast cell tryptase in the circulation after anaphylaxis. J Clin Invest 1989, 83:1551-1555.

\section{doi:10.1186/1710-1492-6-S2-P29}

Cite this article as: Oomah et al:: Prolonged elevation of serum tryptase resulting from intraoperative anaphylaxis to methylene blue. Allergy, Asthma \& Clinical Immunology 2010 6(Suppl 2):P29.

${ }^{1}$ University of Manitoba, Winnipeg, Manitoba, Canada, R3E 3P5

Full list of author information is available at the end of the article 